\title{
Perlindungan Hukum atas Kerugian Nasabah Asuransi Terhadap Kasus Gagal Bayar Ditinjau dari Undang- Undang Nomor 8 Tahun 1999 Tentang Perlindungan Konsumen
}

\author{
Wafa Nihayati Inayah ${ }^{1 凶}$, Marsitiningsih $^{2}$ \\ ${ }^{1}$ Universitas Jenderal Soedirman \\ 2 Universitas Muhammadiyah Purwokerto \\ E-mail Korespondensi: wafanihayati@gmail.com
}

\begin{abstract}
Legal protection for insurance policyholders is essential because it is associated with standard agreements in insurance agreements. In essence, since the signing of the insurance policy, the insured has received less legal protection because the content or format of the agreement is more beneficial to the insurance company. The unequal position between insurance policyholders and insurance companies and the application of standard agreements causes the function of legal protection for insurance policyholders to be questioned. This study discusses how the legal protection for insurance customer losses against default cases in terms of Law Number 8 of 1999 concerning Consumer Protection and the obstacles in legal protection for insurance customer losses against default cases in Law Number 8 of 1999 About Consumer Protection. The method used in this research is the normative juridical method carried out through a literature study that examines secondary data. Insurance customers, in this case, are consumers who use insurance services which, in carrying out their activities, have the right to obtain legal protection from anything that will harm the consumer. Law Number 8 of 1999 concerning Consumer Protection has clearly stated the legal protection provided for consumers using services or insurance customers, namely by making every effort to achieve legal protection for customers.
\end{abstract}

Keywords: Legal Protection, Insurance, Default

\begin{abstract}
Abstrak
Perlindungan hukum terhadap pemegang polis asuransi merupakan hal yang penting sekali, oleh karena dihubungkan dengan praktik perjanjian baku pada perjanjian asuransi, pada hakikatnya sejak penandantanganan polis asuransi, tertanggung sebenarnya sudah kurang mendapatkan perlindungan hukum oleh karena isi atau format perjanjian tersebut lebih menguntungkan pihak perusahaan asuransi. Tidak setaranya kedudukan antara pemegang polis asuransi dengan perusahaan asuransi sebagaimana penerapan perjanjian baku, menyebabkan fungsi perlindungan hukum terhadap pemegang polis asuransi itu dipertanyakan. Penelitian ini membahas bagaimana perlindungan hukum atas kerugian nasabah asuransi terhadap kasus gagal bayar ditinjau dari Undang-undang Nomor 8 Tahun 1999 Tentang Perlindungan Konsumen dan hambatan-hambatan dalam perlindungan hukum atas kerugian nasabah asuransi terhadap kasus gagal bayar ditinjau dari Undang-undang Nomor 8 Tahun 1999 Tentang Perlindungan Konsumen. Metode yang digunakan dalam penelitian ini yaitu Metode yuridis normatif dilakukan melalui studi pustaka yang menelaah data sekunder. Nasabah asuransi, dalam hal ini berkedudukan sebagai konsumen pemakai jasa asuransi yang dalam melakukan aktivitasnya berhak untuk mendapatkan perlindungan hukum dari segala sesuatu yang akan merugikan diri konsumen. Undang-undang Nomor 8 Tahun 1999 tentang Perlindungan Konsumen sudah menyebutkan secara jelas mengenai perlindungan hukum yang diberikan bagi konsumen pemakai jasa atau nasabah asuransi, yaitu dengan melakukan segala upaya demi tercapainya perlindungan hukum bagi nasabah
\end{abstract}

Kata kunci: Perlindungan Hukum, Asuransi, Gagal Bayar 
Kosmik Hukum Vol. 21 No. 2 (2021): 133-141

E-ISSN: 2655-9242 | P-ISSN: 1411-9781

DOI: 10.30595/kosmikhukum.v20i2.9995

\section{Pendahuluan}

Manusia dibelahan dunia manapun setiap saat dihampiri oleh musibah maupun risiko yang datang silih berganti, hal ini perlu ditanggulangi oleh para pihak sehingga dana yang telah dialokasikan untuk kebutuhan yang sudah ditetapkan tidak hilang. Misalnya pemilik usaha yang tokonya terbakar akan kesulitan untuk kembali berdagang karena barang modal yang ia jual sudah habis termakan api, maka dari itu perlu ditanggulangi dengan menggunakan asuransi sebagai proteksi diri dari kerugian yang tidak diinginkan. Asuransi berdasarkan pada Pasal 1 Angka 1 Undang-undang Nomor 40 Tahun 2014 tentang Perasuransian atau pertanggungan secara umum adalah perjanjian antara dua pihak yaitu perusahaan asuransi dan pemegang polis, yang menjadi dasar bagi pemerimaan premi oleh perusahaan asuransi.

Asuransi adalah salah satu bentuk pengendalian resiko yang dilakukan dengan cara mengalihkan atau transfer resiko dari satu pihak ke pihak lain dalam halini perusahaan asuransi. Pihak yang mengalihkan resiko disebutkonsumen. Konsumen membayar sejumlah uangyang disebut premi dan mendapatkan jaminan darisegi keekonomian apabila terjadi resiko. Pihakpenjamin disebut Perusahaan Asuransi. Konsumen bisa mengajukan klaim apabila terjadi musibah kepada Perusahaan Asuransi. Seiring meningkatnyajumlah konsumen asuransi semakin meningkat jugakasus klaim yang terjadi. Klaim ada yang diterimadan ada yang ditolak oleh Perusahaan Asuransi. Kasus klaim yang ditolak menimbulkan ketidakpuasan konsumen dan apabila hal ini terjadi kebanyakan konsumen tidak bisa berbuat banyak. Berdasarkan hal tersebut dibutuhkan sebuah lembaga yang mengatur dan mengawasi praktek bisnis asuransi yang bisa menjembatani apabila terjadi kasus yang melibatkan perusahaan asuransi dan konsumen.

Dengan berkembangnya kebutuhan masyarkat dan upaya perusahaan perasuransian untuk meningkatkan pendapatan maka jenis asuransi pun bertambah. Beberapa produk asuransi yang dikenal masyarakat adalah asuransi kesehatan, asuransi jiwa, asuransi pendidikan, asuransi kendaraan dan lainnya. Diluar uephoria masyarkat dan perusahaan asuransi yang dalam penjualan produk unit link ini sangat besar, juga tersimpan risiko yang besar dengan banyaknya fakta kasus gagal bayar perusahaan asuransi kepada pemegang polis. Pada tahun 2008 perusahaan asuransi Bakrie Life gagal bayar untuk produk asuransi jiwa berbasis investasi dengan produk "Diamond Investa", kegagalan bayar ini menurut pihak Bakrie Life diakibatkan oleh krisis keuangan yang membuat investasi rontok dan mengakibatkan dana nasabah sebanyak Rp. 360 Milyar hilang tidak kembali.

Kasus terbaru yang menggambarkan sulitnya penyelesaian klaim asuransi Jiwasraya dimana penyelesaiannya bisa dikatakan tidak sesuai dengan pertanggungan resiko yang disepakati dalam polis asuransi. Pihak nasabah dalam hal ini merasa tidak menerima nilai pertanggungan sesuai yang dijanjikan karena pihak asuransi memberikan ganti rugi yang tidak sesuaidengan akad perjanjian. Sampai saat ini penyelesaiankasus ini masih belum ada berita dan titik temu yang dapat diterima pihak nasabah. Permasalahan ini pun berlanjut pada perusahaan AJB Bumiputera dan Asuransi Jiwasraya menjadi perusahaan yang mengalami kegagalan

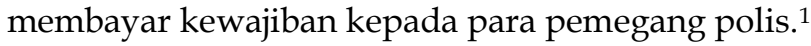

Pada asuransi Jiwasraya gagal bayar ini melibatkan 711 polis senilai Rp802 miliar. ${ }^{2}$ Pada 14 Januari 2020, Kejaksaan Agung (Kejagung) menahan 5 orang yang diduga terlibat kasus Jiwasraya, 3 di antaranya merupakan mantan jajaran direksi PT. Asuransi Jiwasraya (Jiwasraya) yaitu Hendrisman Rahim (Mantan Direktur Utama), Harry Prasetyo (Mantan Direktur Keuangan), dan Syamirwan (Mantan Kepala Divisi Investasi dan Keuangan). Kejahatan korporasi ini diduga kuat menjadi penyebab Jiwasraya gagal membayar kepada nasabah sejumlah Rp802 miliar (Oktober 2018) dan Rp12,4 triliun (Desember 2019). Kondisi ini tentunya

\footnotetext{
Christine Nababan. "INFOGRAFIS: Deretan Kasus Gagal Bayar Asuransi Raksasa." 2019. https://www.cnnindonesia.com/ekonomi/201904050 65809-81-383575/infografis-deretan-kasus-gagalbayarasuransi-raksasa. diakses pada 1 Mei 2020 jam 10:45 WIB.

2 Risca Vilana. “Pamor Unit dan Link Saving Plan Setelah Kasus Jiwasraya." 2019. http://infobanknews.com/pamorunit-link-dansaving-plan-setelah-kasus-jiwasraya/. diakses pada 1 Mei 2020 jam 10:50 WIB.
} 
meresahkan bagi 7,7 juta jiwa nasabahnya. ${ }^{3}$ Masyarakat pemakai jasa asuransi yang selanjutnya disebut sebagai nasabah asuransi, dalam hal ini berkedudukan sebagai konsumen pemakai jasa asuransi yang dalam melakukan aktivitasnya berhak untuk mendapatkan perlindungan hukum dari segala sesuatu yang akan merugikan diri konsumen.

Seperti yang dijelaskan dalam Pasal 1 ayat (1) Undang-undang Nomor 8 Tahun 1999 tentang Perlindungan Konsumen, yang berbunyi :"Perlindungan konsumen adalah segala upayayang menjamin adanya kepastian hukum untuk memberikan perlindungan kepada konsumen." Undang-undang Nomor 8 Tahun 1999 tentang Perlindungan Konsumen sudah menyebutkan secara jelas mengenai perlindungan hukum yang diberikan bagi konsumen pemakai jasa atau nasabah asuransi, yaitu dengan melakukan segala upaya demi tercapainya perlindungan hukum bagi nasabah. Peraturan yang melindungi kepentingan konsumen bisa dikatakan sudah sangat memadai dari segi substansi hukumnya. Perlindungan konsumen diatur dalam Undang-undang Nomor 8 Tahun 1999 tentang Perlindungan Konsumen. Bahkan khusus untuk perlindungan konsumen sektor jasa keuangan, OJK telah menerbitkan POJK No 1/POJK.07/2013 tentang Perlindungan Konsumen Sektor Jasa Keuangan dan POJK No 18/ POJK.07/2018 tentang Layanan Pengaduan Konsumen di Sektor Jasa Keuangan.

Meminjam teori Lawrence M. Friedman, bahwa efektif tidaknya suatu hukum atau aturan tergantung 3 hal, yaitu legal substance (substansi hukum), legal structure (aparat penegak hukum), dan legal culture (buday hukum). Meskipun secara substansi hukum sudah mencukupi, namun legal structure-nya masih belum efektif. Konsumen pemegang polis JS Saving Plan bahkan sudah melakukan pengaduan ke DPR. Badan Perlindungan Konsumen Nasional sudah meminta kepada negara untuk memulihkan hak konsumen dan melakukan proses penegakan hukum konsumen Jiwasraya. Dalam POJK No 1/POJK.07/2013 pasal 39 ayat 1 disebutkan bahwa dalam hal tidak mencapai kesepakatan penyelesaian pengaduan, konsumen dapat melakukan penyelesaian sengketa di luar pengadilan atau melalui pengadilan. Namun untuk berperkara di jalur pengadilan, bukanlah hal yang mudah, konsumen akan tersita waktu dan tenaga serta terbebani biaya perkara seperti untuk pengacara dan biaya lainnya. Dalam pasal 41 disebutkan pemberian fasilitas penyelesaian pengaduan konsumen oleh OJK dilakukan terhadap pengaduan yang berindikasi sengketa di sektor jasa keuangan.

Konsumen yang melakukan pengaduan ke Jiwasraya hanya dijawab tertulis dengan janji bahwa akan membayar hak konsumen tanpa ada kepastian waktu pembayaran. Sesuai Undangundang Nomor 8 Tahun 1999 tentang Perlindungan Konsumen pasal 19 disebutkan bahwa pelaku usaha bertanggung jawab memberikan ganti rugi atas kerusakan, pencemaran, dan/atau kerugian konsumen akibat mengonsumsi barang dan/atau jasa yang dihasilkan atau diperdagangkan. Dengan demikian sesuai undang-undang tersebut, Jiwasraya berkewajiban memberikan ganti rugi kepada konsumen atas tidak diterimanya pembayaran polis sesuai jatuh tempo, karena konsumen menanggung opportunity cost. Ironisnya, kasus Jiwasraya saat ini bukan lagi hanya masalah hokum tapi sudah dibawa ke ranah politik. Hal ini berpotensi menyebabkan perlindungan konsumen menjadi kabur. Dalam negara hukum seharusnya politik tidak bisa mengalahkan hukum, walaupun hokum adalah produk politik. Kalau terjadi, maka nasib konsumen Jiwasraya akan semakin blunder.

Konsumen seharusnya dilindungi karena konsumen adalah pelaku ekonomi. Ketidakpastian pembayaran polis berpotensi menurunkan kepercayaan masyarakat kepada asuransi. Kemajuan ekonomi suatu Negara didorong oleh kemajuan industry asuransi. Ini memang pilihan sulit. Perlindungan hukum terhadap pemegang polis asuransi merupakan hal yang penting sekali, oleh karena dihubungkan dengan praktik perjanjian baku pada perjanjian asuransi, pada hakikatnya sejak penandantanganan polis asuransi, tertanggung sebenarnya sudah kurang mendapatkan perlindungan hukum oleh karena isi atau format perjanjian tersebut lebih menguntungkan pihak perusahaan asuransi. Tidak setaranya kedudukan antara pemegang

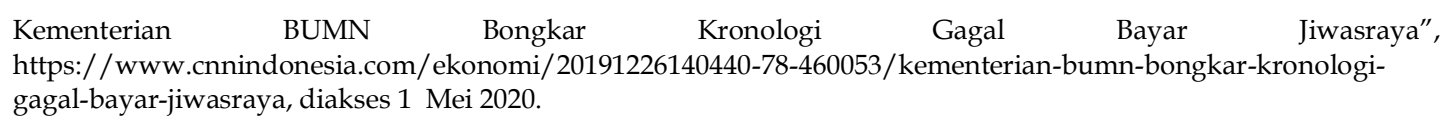


polis asuransi dengan perusahaan asuransi sebagaimana penerapan perjanjian baku, menyebabkan fungsi perlindungan hukum terhadap pemegang polis asuransi itu dipertanyakan.

Salah satu institusi yang berwenang dan berfungsi di dalam memberikan perlindungan hukum tersebut ialah Otoritas Jasa Keuangan (OJK) sebagaimana diatur dalam Undang-undang Nomor 21 Tahun 2011 Tentang Otoritas Jasa Keuangan, yang pada Pasal 55 ayat (1) menyatakan bahwa:"Sejak tanggal 31 Desember 2012, fungsi, tugas, dan wewenang pengaturan dan pengawasan kegiatan jasa keuangan di sektor pasar modal, perasuransian, dana pensiun, lembaga pembiayaan, dan lembagajasa keuangan lainnya be ralih dari Menteri Keuangan dan Badan Pengawas Pasar Modal dan Lembaga Keuangan ke Otoritas Jasa Keuangan (OJK)." Manakal timbul perselisihan atau persengketaan di antara pemegang polis asuransi dengan perusahaan asuransi, maka sesuai dengan fungsi, tugas dan kewenangannya pada otoritas jasa keuangan melakukan mekanisme penyelesaian sengketa konsumen baik melalui peradilan atau litigasi, maupun penyelesaian sengketa di luar peradilan atau non-litigasi.

Permasalahannya ialah sejauhmana perlindungan pemegang polis asuransi diwujudkan. Menurut NurnaningsihAmriani dikemukakannya bahwa:"Secara teoretis ada dua cara yang dapat ditempuh dalam menghadapi atau menyelesaikan sengketa, yaitu secara adversarial atau litigasi (arbitrase atau pengadilan) dan secara kooperatif (negosiasi, mediasi, atau konsiliasi). ${ }^{4}$ Berdasarkan hal tersebut diatas, penulis ingin mengetahui sekaligus mendalami lebih lanjut mengenai kasus ini sebagai langkah untuk memberikan informasi, penjelasan dan pengetahuan kepada masayarakat mengenai perlindungan hukum terhadap nasabah asuransi PT Jiwasraya Persero, maka penulis mengambil topik pembahasan ini dengan judul "Perlindungan Hukum Atas Kerugian Nasabah Asuransi Terhadap Kasus Gagal Bayar Ditinjau Dari UndangUndang Nomor 8 Tahun 1999 Tentang Perlindungan Konsumen."

\section{Rumusan Masalah}

1. Bagaimana perlindungan hukum atas kerugian nasabah asuransi terhadap kasus gagal bayar ditinjau dari Undang-undang Nomor 8 Tahun 1999 Tentang Perlindungan Konsumen?

2. Apa hambatan-hambatan dalam perlindungan hukum atas kerugian nasabah asuransi terhadap kasus gagal bayar ditinjau dari Undang-undang Nomor 8 Tahun 1999 Tentang Perlindungan Konsumen?

\section{Metode Penelitian}

Penelitian ini adalah penelitian hukum (Legal Research) karena menganalisis permasalahan sosial melalui perspektif hukum. Penelitian hukum dibagi menjadi dua aspek yakni penelitian hukum yang aspeknya normatif dan penelitian hukum yang aspeknya empiris. Metode pendekatan penelitian ini adalah yuridis normatif. Metode yuridis normatif dilakukan melalui studi pustaka yang menelaah data sekunder yang berupa Peraturan Perundang-undangan, putusan pengadilan, perjanjian, kontrak, atau dokumen hukum lainnya, serta hasil penelitian, hasil pengkajian, dan referensi lainnya. ${ }^{5}$ Penelitian ini didukung oleh literatur-literatur yang terkait dengan masalah yang diteliti 6 . Pengumpulan data dilakukan dengan studi kepustakaan (Library Research) untuk mendapatkan data yang berbentuk dokumen dan tulisan melalui penelusuran peraturan perundang-undangan, dokumen, literatur ilmiah, penelitian para ahli. Penelitian ini menggunakan sumber utama data sekunder atau bahan pustaka. Data sekunder meliputi bahan hukum primer, bahan hukum sekunder dan bahan hukum tersier. Jenis data

\footnotetext{
4 Nurnaningsih Amriani, Mediasi. Alternatif Penyelesaian Sengketa Perdata di Pengadilan, (Jakarta : RajaGrafindo Persada, 2011), 19

5 Badriyah Khaleed, Legislative Drafting Teori dan Praktik Penyusunan Peraturan Perundang-undangan, (Yogyakarta: Medpress Digital, 2014), 41.

6 Salim HS, Penerapan Hukum pada Penelitian Tesis dan Desertasi, (Jakarta: PT Rajagrafindo, 2013), 26.
} 
adalah data sekunder berupa data kualitatif yang selanjutnya dianalisis dengan peraturan yang berkaitan dengan masalah yang diteliti. ${ }^{7}$ Kemudian data yang telah dikumpulkan dan dianalisis tersebut dikaji kembali dengan pendekatan triangulasi yang bertujuan untuk memverifikasi kebenaran data yang diperoleh peneliti dari berbagai sudut pandang yang berbeda. ${ }^{8}$

\section{Hasil dan Pembahasan}

\section{Perlindungan hukum atas kerugian nasabah asuransi terhadap kasus gagal bayar ditinjau dari Undang-undang Nomor 8 Tahun 1999 Tentang Perlindungan Konsumen}

Hakekat kehidupan manusia di dunia selalu dihadapkan pada peristiwa yang tidak pasti. Peristiwa ketidakpastian itu dapat mengakibatkan keuntungan atau kerugian. Besarnya kerugian tersebut akan berpengaruh pada berkurangnya atau lenyapnya nilai ekonomis hidupnya. ${ }^{9}$ Resiko merupakan suatu bagian yang tidak terlepas dari kehidupan manusia sehari-hari. Manusia selalu dihadapkan terhadap sebuah resiko yang akan terjadi. Dapat dilihat dalam pengertian resiko itu sendiri, bahwa resiko adalah bahaya, akibat atau konsekuensi yang dapat terjadi atau akibat sebuah proses atau kegiatan yang sedang berlangsung atau kejadian yang akan datang. ${ }^{10}$ Suatu kegiatan atau proses yang memiliki sebuah resiko atau konsekuensi salah satunya adalah kegiatan asuransi. Asuransi merupakan suatu jasa yang dapat membantu untuk menghindari atau meminimalisir resiko-resiko yang mungkin atau yang akan dialami. Hal ini memberikan kesimpulan bahwa segala kerugian yang mungkin timbul di masa yang akan datang dipindahkan kepada penanggung. ${ }^{11}$

Industri asuransi merupakan sarana pengerahan dan pemupukan dana masyarakat, disamping berperan sebagai sarana perlindungan terhadap resiko. Artinya, asuransi merupakan salah satu lembaga keuangan yang patut diperhitungkan terutama dukungan investasi dalam pembiayaan pembangunan dan meningkatkan kesejahteraan masyarakat. ${ }^{12}$ Perusahaan asuransi memiliki karakteristik tersendiri karena produk yang dijual disini adalah tidak nyata karena tidak dapat dilihat dan disentuh. Tidak seperti produk lain, produk asuransi hanya dapat dirasakan manfaatnya karena produk yang dijual pada asuransi sebenarnya adalah tanggung jawab dari pihak penanggung dalam memberikan penggantian atas kerugian yang diterima oleh pihak tertanggung terhadap obyek asuransi. ${ }^{13}$ Peningkatan efisiensi dan menekan biaya yang bertujuan sebagai kebutuhan utama menyebabkan industri asuransi perlu memperbaiki sistem dan prosedur yang selama ini dianut. Bila diperlukan harus dilakukan secara menyeluruh dan menyentuh, karena hal ini bertujuan untuk mengurangi adanya klaim. ${ }^{14}$

Klaim adalah permintaan resmi yang ditujukan kepada perusahaan asuransi terkait perlindungan finansial atau ganti rugi dari pihak tertanggung sesuai dengan kontrak perjanjian yang telah disepakati antara tertanggug dengan perusahaan penyedia jasa asuransi (Penanggung). Sebelum klaim asuransi disetujui biasanya perusahaan akan meninjau beberapa ketetapan sebelum permintaan disetujui. ${ }^{15}$ Asuransi merupakan bisnis yang mempertaruhkan kredibilitas suatu perusahaan, kepercayaan masyarakat khususnya konsumen adalah yang utama, karena tanpa kepercayaan, industri ini akan mati secara perlahan-lahan,maka suatu perusahaan wajiblah bertanggungjawab penuh terhadap konsumen. ${ }^{16}$ Untuk menjaga

Mathew, Miles dan Michel Huberman, Analisis Data Kualitatif : Buku Sumber tentang Metode-metode Baru,( Jakarta: UI Pres, 2009), hlm 102.

Sugiyono, Metodologi Penelitian Pendidikan, (Bandung: Alfabeta, 2007), 303.

9 Suisno, " Tinjauan Yuridis Tindak Pelanggaran Usaha Perasuransian Menurut Undang-Undang Nomor 40 Tahun 2014 Tentang Perasuransian," Jurnal Independent, Vol. 3, No. 1, (2015): 21.

10 Djoko Prakoso dan I Ketut Murtika, Hukum Asuransi Indonesia, (Jakarta: Rineka Cipta, 2004), 13. Ibid

Sunarmi, “Pemegang Polis Asuransi dan Kedudukan Hukumnya," Jurnal Ilmu Hukum, Vol.3 No.1. (2013), 5.

Junaedy Ganei, Hukum Asuransi Indonesia, (Jakarta: Sinar Grafika, 2013), 5.

14 Neni Sri Imaniyati, Perlindungan Hukum Dalam Sengketa Klaim Asuransi, Jurnal Hukum Bisnis, Vol. 30, No.1. (2011), 12.

15 Ketut Sendra, Klaim Asuransi Gampang, (Jakarta: PPM, 2009), 29.

16 Kornelius Simanjuntak, dkk., Hukum Asuransi, (Jakarta: Bumi Aksara, 2011), 12. 
kepercayaan tersebut dibutuhkan kerjasama serta itikad yang baik dari pihak penanggung maupun pihak tertanggung untuk dapat melaksanakan perjanjian asuransi seperti yang telah tercantum dalam polis. Penanggung dalam membangun jalur pemasaran yang menjadi penghubung antara penanggung dan tertanggung, memerlukan perusahaan asuransi yang berfungsi menjadi basis pemasaran produk dari penanggung tersebut. Perusahan asuransi berperan penting sebagai jembatan komunikasi antara penanggung dan tertanggung. ${ }^{17}$ Jika terjadi suatu evenemen pada tertanggung, penanggung akan bertanggungjawab dengan membayar uang pertanggungan sesuai dengan yang diperjanjikan sebelumnya. Terjadinya ketidakbenaran dalam penyampaian informasi produk akan berdampak pada klaim tertanggung yang ditujukan pada penanggung. ${ }^{18}$

Suatu kegiatan asuransi dapat kita simpulkan sesuai fungsinya bahwa pihak penanggung diibaratkan sebagai pelaku usaha dan nasabah diibaratkan sebagai konsumen. Kenyataan bahwa pelaku usaha dan konsumen adalah dua pihak yang saling memerlukan satu sama lain adalah benar adanya karena agen asuransi memerlukan nasabah di dalam mata pencahariannya, begitu pula konsumen sebagai nasabah memerlukan barang dan jasa dari pelaku usaha asuransi guna memenuhi keperluannya. Di dalam kenyataanya, seringkali konsumen dirugikan oleh pelaku usaha/penanggung yang tidak jujur dan suka memanfaatkan keadaan pihak konsumen yang apabila ditinjau dari aspek hukum merupakan tindak pelanggaran hukum. ${ }^{19}$

Hal ini mengakibatkan pihak konsumen membayar sejumlah uang namun hal tersebut ternyata di dalam kenyataanya sangat tidak ada manfaatnya bagi konsumen itu sendiri. Di sisi lain, karena ketidaktahuan dan ketidaksadaran konsumen akan haknya sebagai konsumen, maka konsumen menjadi korban dari pelaku usaha/penanggung yang curang. Guna melindungi dan menumbuh kembangkan kesadaran konsumen akan hak-haknya, Pemerintah Indonesia mengeluarkan Undang-undang Nomor 8 Tahun 1999 tentang Perlindungan Konsumen (selanjutnya disingkat dengan UUPK) sebagai payung hukum perlindungan konsumen di Indonesia. ${ }^{20}$ Dalam transaksi perdagangan konsumen penting diberikan sebuah perlindungan. Pentingnya perlindungan hukum bagi konsumen disebabkan posisi tawar konsumen yang lemah. Perlindungan hukum terhadap konsumen mensyaratkan adanya pemihakan kepada posisi tawar yang lemah (konsumen).

Perlindungan hukum sangat dibutuhkan dalam persaingan dan banyaknya produk serta layanan yang menempatkan konsumen dalam posisi tawar yang lemah. ${ }^{21}$ Hak konsumen untuk mendapatkan perlindungan diantaranya adalah hak atas kenyamanan, keamanan, dan keselamatan dalam mengonsumsi barang dan atau jasa, hak untuk memilih barang dan atau jasa sertamendapatkan barang dan atau jasa tersebut sesuai dengan nilai tukar dan kondisi serta jaminan yang dijanjikan hak untuk diperlakukan atau dilayani secara benar dan jujur serta tidak diskriminasi, hak untuk mendapatkan kompensasi, ganti rugi dan atau penggantian, apabila barang dan atau jasa yang diterima tidak sesuai dengan perjanjian atau tidak sebagaimana mestinya, dan sebagainya.

Pengertian perlidungan konsumen menurut undang-undang Nomor 8 Tahun 1999 tentang Perlindungan Konsumen, perlindungan konsumen adalah segala upaya yang menjamin adanya kepastian hukum untuk memberikan perlindungan kepada konsumen. Dalam undang-undang ini bukan berarti kepentingan pelaku usaha tidak ikut menjadi perhatian, karena keberadaan perekonomian nasional banyak ditentukan oleh para pelaku usaha. Kesewenang-wenangan akan mengakibatkan ketidakpastian hukum. ${ }^{22}$ Oleh karena itu,agar segala upaya memberikan jaminan akan kepastian hukum, maka ditentukanlah undang-undang mengenai perlindungan konsumen ini. Undang-undang lainnya yang juga dimaksudkan dan masih berlaku untuk memberikan perlindungan Konsumen yaitu dalam POJK yang mengenai perlindungan konsumen pada sektor

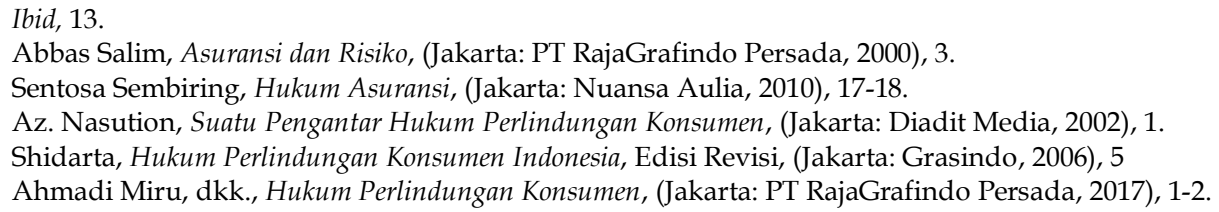


jasa keuangan, disini menjelaskan bahwa perlindungan konsumen itu adalah perlindungan terhadap konsumen dengan cakupan perilaku pelaku usaha jasa keuangan. ${ }^{23}$

Pasal 1 angka 1 Undang-undang Nomor 8 Tahun 1999 tentang Perlindungan Konsumen menjelaskan bahwa perlindungan konsumen adalah segala upaya yang menjamin adanya suatu kepastian hukum untuk memberikan perlindungan kepada konsumen. Selain Undang-undang Nomor 8 Tahun 1999 tentang Perlindungan Konsumen ada pengaturan yang lebih khusus membahas perlindungan konsumen yaitu POJK No. 1/POJK.07/2013 yang membahas tentang perlindungan konsumen bagi sektor jasa keuangan. Dapat diketahui bahwa dalam berasuransi tentu akan ada suatu masalah dimana pihak konsumen akan meminta permohonan klaim kepada pihak asuransi atas kerugian yang dialami oleh pihak konsumen tersebut,yang kemungkinkan bahwa pihak asuransi tidak mengabulkan permohonan klaim dari pihak konsumen dengan alasan hukum sesuai peraturan perusahaan asuransi tersebut, maka dengan adanya undang-undang Nomor 8 Tahun 1999 tentang Perlindungan Konsumen sebagai hukum dasar perlindungan konsumen di Indoneisa dan sebagai acuan dari POJK No. 1/POJK.07/2013 sangat membantu konsumen untuk meminta haknya kepada perusahaan asuransi yang bersangkutan dan konsumen merasa terlindungi. Dalam Pasal 3 POJK No. 1/POJK.07/2013 terdapat hak dan kewajiban pelaku usaha jasa keuangan yaitu untuk memastikan adanya itikad baik Konsumen dan mendapatkan informasi atau dokumen mengenai Konsumen yang akurat, jujur, jelas, dan tidak menyesatkan. Dan dalam Pasal 40 POJK No. 1/POJK.07/2013 diatur mengenai hak konsumen untuk mendapatkan perlindungan konsumen, hak-hak konsumen itu adalah:

a. Konsumen dapat menyampaikan pengaduan yang berindikasi sengketa antara Pelaku Usaha Jasa Keuangan dengan Konsumen kepada Otoritas Jasa Keuangan.

b. Konsumen atau masyarakat dapat menyampaikan pengaduan yang berindikasi pelanggaran atas ketentuan peraturan perundang-undangan di sektor jasa keuangan kepada Otoritas Jasa Keuangan.

Dalam POJK No. 1/POJK.07/2013 tidak membahas mengenai kewajiban dari konsumen. Oleh karena itu, kententuan pengaturan kewajiban konsumen di atur dalam Pasal 5 Undangundang Nomor 8 Tahun 1999 tentang Perlindungan Konsumen sebagai landasan peraturan perlindungan konsumen di Indonesia. Sesuai dengan asas lex superior derogat legi inferior yang artinya peraturan yang lebih tinggi mengesampingkan yang rendah.

\section{Hambatan-hambatan dalam perlindungan hukum atas kerugian nasabah asuransi terhadap kasus gagal bayar ditinjau dari Undang-undang Nomor 8 Tahun 1999 Tentang Perlindungan Konsumen}

Berdasarkan hasil penelitian yang telah diuraikan sebelumnya, terdapat beberapa faktor yang menyebabkan terjadinya hambatan dalam memberikan perlindungan hukum terhadap nasabah asuransi tersebut, antara lain:

a. Tidak efektifnya upaya hukum terhadap penyelesaian sengketa di bidang asuransi. Berbagai upaya hukum dilaksanakan dan ditempuh oleh para tertanggung untuk menyelesaikan sengketa dengan penanggungnya. Akan tetapi, solusi atas sengketa ini tidak berhasil ditemukan untuk mengatasi permasalahan gagal bayar. Berbagai upaya hukum yang tersedia tidak dapat mengakomodasikan keinginan para tertanggung untuk mendapatkan dananya kembali. Salah satu faktor penghambat dalm penyelesaian sengketa ini adalah substansi tentang upaya hukum yang diatur dalam peraturan perundang-undangan Indonesia tidak berpihak terhadap para tertanggung. Adanya susbtansi hukum yang tidak efektif ini tentunya menjadi penghalang bagi para tertanggung untuk melakukan penyelesaian sengketa dengan para penanggung tersebut.

b. Ketidaktegasan aparatur penegak hukum terhadap penanganan permasalahan. Aparatur penegak hukum merupakan bagian dari unsur sistem hukum. Aparatur hukum bagian dari

23 Indonesia (POJK), Pengaturan Otoritas Jasa Keuangan, Pengaturan Otoritas Jasa Keuangan Nomor $1 /$ POJK.07/2013 Tentang Perlindungan Konsumen pada Sektor Jasa Keuangan, LN Tahun 2011 Nomor 111, TLN Nomor 118, Bab 1 Pasal 1 angka 3. 
struktur hukum yang dapat mempengaruhi kelancaran dan berjalannya sistem hukum yang berlandaskan pada kepastian hukum. Aparatur penegak hukum ini harus bertindak tanggap dan tegas dalam mendukung pelaksanaan dari sistem hukum yang efektif. Berkaitan dengan permasalahan gagal bayar, peranan aparatur penegak hukum tentunya berperan penting terhadap penegakkan hukum untuk mencapai keadilan terhadap para tertanggung asuransi. Ketidaktegasan aparatur penegak hukum dalam penanganan permasalahan tindakan wanprestasi yang dilakukan oleh perusahaan asuransi. Peranan aparatur penegak hukum ini seharusnya terletak pada pemerintah melalui Otoritas Jasa Keuangan. Otoritas Jasa Keuangan seharusnya menjalankan fungsi sebagai lemabaga pengawasan terhadap kegiatan di bidang pasar modal dan lembaga keuangan. Adanya tindakan tegas dari Otoritas Jasa Keuangan terhadap tindakan corporate action dari Perusahaan asuransi dapat menjadi tindakan pencegahan secara dini.

\section{Penutup}

\section{Kesimpulan}

Dapat diketahui bahwa dalam berasuransi tentu akan ada suatu masalah dimana pihak konsumen akan meminta permohonan klaim kepada pihak asuransi atas kerugian yang dialami oleh pihak konsumen tersebut,yang kemungkinkan bahwa pihak asuransi tidak mengabulkan permohonan klaim dari pihak konsumen dengan alasan hukum sesuai peraturan perusahaan asuransi tersebut, maka dengan adanya Undang-undang Nomor 8 Tahun 1999 tentang Perlindungan Konsumen ada pengaturan yang lebih khusus membahas perlindungan konsumen yaitu POJK No. 1/POJK.07/2013 yang membahas tentang perlindungan konsumen bagi sektor jasa keuangan. Dapat diketahui bahwa dalam berasuransi tentu akan ada suatu masalah dimana pihak konsumen akan meminta permohonan klaim kepada pihak asuransi atas kerugian yang dialami oleh pihak konsumen tersebut,yang kemungkinkan bahwa pihak asuransi tidak mengabulkan permohonan klaim dari pihak konsumen dengan alasan hukum sesuai peraturan perusahaan asuransi tersebut, maka dengan adanya undang-undang Nomor 8 Tahun 1999 tentang Perlindungan Konsumen sebagai hukum dasar perlindungan konsumen di Indoneisa dan sebagai acuan dari POJK No. 1/POJK.07/2013 sangat membantu konsumen untuk meminta haknya kepada perusahaan asuransi yang bersangkutan dan konsumen merasa terlindungi.

Berdasarkan hasil penelitian yang telah diuraikan sebelumnya, terdapat beberapa faktor yang menyebabkan terjadinya hambatan dalam memberikan perlindungan hukum terhadap nasabah asuransi tersebut, antara lain; Pertama, tidak efektifnya upaya hukum terhadap penyelesaian sengketa di bidang asuransi. Berbagai upaya hukum dilaksanakan dan ditempuh oleh para tertanggung untuk menyelesaikan sengketa dengan penanggungnya. Akan tetapi, solusi atas sengketa ini tidak berhasil ditemukan untuk mengatasi permasalahan gagal bayar. Berbagai upaya hukum yang tersedia tidak dapat mengakomodasikan keinginan para tertanggung untuk mendapatkan dananya kembali. Kedua, ketidaktegasan aparatur penegak hukum terhadap penanganan permasalahan. Aparatur penegak hukum merupakan bagian dari unsur sistem hukum. Aparatur hukum bagian dari struktur hukum yang dapat mempengaruhi kelancaran dan berjalannya sistem hukum yang berlandaskan pada kepastian hukum. Aparatur penegak hukum ini harus bertindak tanggap dan tegas dalam mendukung pelaksanaan dari sistem hukum yang efektif. Berkaitan dengan permasalahan gagal bayar, peranan aparatur penegak hukum tentunya berperan penting terhadap penegakkan hukum untuk mencapai keadilan terhadap para tertanggung asuransi. Ketidaktegasan aparatur penegak hukum dalam penanganan permasalahan tindakan wanprestasi yang dilakukan oleh perusahaan asuransi. Peranan aparatur penegak hukum ini seharusnya terletak pada pemerintah melalui Otoritas Jasa Keuangan. Otoritas Jasa Keuangan seharusnya menjalankan fungsi sebagai lemabaga pengawasan terhadap kegiatan di bidang pasar modal dan lembaga keuangan. 


\section{Saran}

a. Otoritas Jasa Keuangan seharusnya melakukan pemberitahuan kepada masyarakat baik melalui media massa maupun elektronik terhadap produk asuransi yang memiliki indikasi gagal bayar. Pemberitahuan ini mencegah masyarakat membeli produk asuransi yang tidak sehat.

3. Pemerintah Indonesia sebagai badan pengawas asuransi perlu meningkatkan peran dan fungsi pengawasannya kepada perusahaan-perusahaan asuransi agar di kemudian hari tidak terjadi lagi kasus gagal bayar oleh perusahaan asuransi dan melakukan pembatasan penempatan investasi lebih ketat terhadap perusahaan asuransi.

\section{Daftar Pustaka}

Amriani, Nurnaningsih. Mediasi. Alternatif Penyelesaian Sengketa Perdata di Pengadilan. Jakarta: RajaGrafindo Persada, 2011.

Ganei, Junaedy. Hukum Asuransi Indonesia. Jakarta: Sinar Grafika, 2013.

HS, Salim. Penerapan Hukum pada Penelitian Tesis dan Desertasi. Jakarta: PT Rajagrafindo, 2013.

I Ketut Murtika, Djoko Prakoso. Hukum Asuransi Indonesia. Jakarta: Rineka Cipta, 2004.

Kementerian BUMN Bongkar Kronologi Gagal Bayar Jiwasraya", https://www.cnnindonesia.com/ekonomi/20191226140440-78-460053/kementerian-bumnbongkar-kronologi-gagal-bayar-jiwasraya, diakses 1 Mei 2020.

Khaleed, Badriyah. Legislative Drafting Teori dan Praktik Penyusunan Peraturan Perundangundangan. Yogyakarta: Medpress Digital, 2014.

Michel Huberman, Mathew, Miles. Analisis Data Kualitatif: Buku Sumber tentang Metode-metode Baru. Jakarta: UI Pres, 2009.

Miru, Ahmadi, dkk. Hukum Perlindungan Konsumen Jakarta: PT RajaGrafindo Persada, 2017.

Nababan, Christine. "INFOGRAFIS: Deretan Kasus Gagal Bayar Asuransi Raksasa." 2019. https://www.cnnindonesia.com/ekonomi/201904050 65809-81-383575/infografis-deretankasus-gagalbayar-asuransi-raksasa."

Nasution, Az. 2002. Suatu Pengantar Hukum Perlindungan Konsumen. Jakarta: Diadit Media.

Pengaturan Otoritas Jasa Keuangan Nomor 1 /POJK.07/ 2013 Tentang Perlindungan Konsumen pada Sektor Jasa Keuangan.

Salim, Abbas. Asuransi dan Risiko. Jakarta: PT RajaGrafindo Persada, 2000.

Sembiring, Sentosa. Hukum Asuransi. Jakarta: Nuansa Aulia, 2010.

Sendra, Ketut. Klaim Asuransi Gampang. Jakarta: PPM, 2009.

Shidarta. Hukum Perlindungan Konsumen Indonesia, Edisi Revisi, Jakarta: Grasindo, 2006.

Simanjuntak, Kornelius, dkk. Hukum Asuransi. Jakarta: Bumi Aksara, 2011.

Sri Imaniyati, Neni. "Perlindungan Hukum Dalam Sengketa Klaim Asuransi." Jurnal Hukum Bisnis. Vol.30, No.1 (2011).

Sugiyono. Metodologi Penelitian Pendidikan. Bandung: Alfabeta, 2007.

Suisno. “Tinjauan Yuridis Tindak Pelanggaran Usaha Perasuransian Menurut Undang-Undang Nomor 40 Tahun 2014 Tentang Perasuransian" Jurnal Independent, Vol. 3, No. 1 (2015).

Sunarmi. “Pemegang Polis Asuransi dan Kedudukan Hukumnya." Jurnal Ilmu Hukum, Vol.3 No.1 (2013.).

Vilana, Risca. "Pamor Unit dan Link Saving Plan Setelah Kasus Jiwasraya." 2019. http://infobanknews.com/pamor-unit-link-dansaving-plan-setelah-kasus-jiwasraya/. 